\title{
Uji Produktivitas Berbagai Varietas Jagung (Zea mays L.) Hibrida dan Non Hibrida yang Sesuai pada Agroekosistem Kabupaten Polewali Mandar
}

\author{
${ }^{1}$ Harli A. Karim*, ${ }^{2}$ M. Yasin HG., ${ }^{3}$ Hasanuddin Kandatong, ${ }^{4}$ Hasan, ${ }^{5}$ Hikmahwati, ${ }^{6}$ Fitrianti \\ 1,3,4,5,6 Program Studi Agroteknologi Universitas Al Asyariah Mandar \\ ${ }^{2}$ Balai Penelitian Serealia Maros Sulawesi Selatan \\ Email : *harlipertanian@gmail.com
}

\begin{abstract}
Abstrak
Jagung merupakan komoditas strategis setelah komoditas padi, yakni selain dikonsumsi sebagai bahan pangan langsung dan pakan ternak, juga digunakan sebagai bahan baku industri lainnya, seperti bahan bakar alternatif (biofuel), polymer, minyak jagung dan lainnya. Permintaan jagung baik untuk industri pangan, pakan, dan kebutuhan industri lainnya dalam beberapa tahun ke depan diproyeksikan akan terus meningkat. Berbagai varietas jagung telah dilepas. Namun demikian masih terdapat varietas jagung yang belum mencapai produktivitas optimum. Salah satunya disebabkan ketidaksesuai ekosistem. Kabupaten Polewali Mandar merupakan daerah pengembangan jagung. Penelitian ini bertujuan untuk menguji Pertumbuhan dan Produksi berbagai Varietas Jagung yang Sesuai dengan Agroekosistem Kabupaten Polewali Mandar. Penelitian ini dilaksanakan pada bulan Januari-April 2019 di Desa Tumpiling Kecamatan Wonomulyo Kabupaten Polewali mandar Provinsi Sulawesi Barat. Penelitian ini menggunakan Rancangan Acak Kelompok yang terdiri dari 7 varietas jagung yaitu, varietas BISI 18, Pertiwi, OPV Srikandi A. Depu, Anoman 1, Bima 12Q, URI 3, dan Sukmaraga. Hasil penelitian menunjukkan bahwa uji berbagai varietas jagung memberikan pengaruh sangat nyata terhadap tinggi tanaman jagung 2 MST dan berpengaruh nyata 10 MST, umur berbunga, panjang tongkol. BISI 18 dan Pertiwi memberikan hasil terbaik terhadap jumlah daun 8 MST, Pertiwi memberikan pengaruh terbaik terhadap jumlah biji dalam baris namun tidak berbeda nyata dengan BISI 18, Pertiwi memberikan hasil terbaik terhadap berat biji tanaman jagung namun tidak berbeda nyata dengan BISI 18 dan Sukmaraga, Pertiwi memberikan hasil terbaik terhadap produktivitas tanaman jagung namun tidak berbeda nyata dengan BISI 18 dan Sukmaraga.
\end{abstract}

Kata Kunci : produktivitas, varietas jagung, hibrida, ekosistem

\section{Pendahuluan}

Jagung merupakan komoditas strategis setelah komoditas padi, yakni selain dikonsumsi sebagai bahan pangan langsung dan pakan ternak, juga digunakan sebagai bahan baku industrilainnya, seperti bahan bakar alternatif (biofuel), polymer, minyak jagung dan lainnya (Widowati, 2012). Permintaan jagung baik untuk industri pangan, pakan, dan kebutuhan industri lainnya dalam beberapa tahunke depan diproyeksikan akan terus meningkat.

Peningkatan produksi jagung untuk memenuhi kebutuhan dalam negeri telah diupayakan oleh pemerintah melalui berbagai kebijakan dan program Upsus Padi Jagung Kedelai (Pajale). Beberapa program pemerintah dalam rangka meningkatkan produksi antara lain yaitu peningkatan produktivitas (penerapan teknologi tepat guna spesifik lokasi), penggunaanvarietas unggul bermutu (Ali, et., al, 2014).

Produksi jagung nasional lima tahun terakhir (20132017) meningkat rata-rata $8,02 \%$ pertahun. Peningkatan cukup signifikan terjadi pada dua tahun terakhir yaitu tahun 2016 dan 2017. Produksi jagung tahun 2016 sebesar 23,58 juta ton, meningkat sekitar 3,96 juta ton dibandingkan tahun 2015 atau meningkat sebesar 20,22\%. Pada tahun 2017 produksi jagung kembali meningkat signifikan sebesar $18,55 \%$, dari 23,58 juta ton tahun 2016 menjadi sekitar 27,95 juta ton (Pusat Data dan Sistem Informasi PertanianSekretariat Jenderal Kementerian Pertanian, 2017).

Produktivitas jagung di tingkat petani berfluktuasi antara satu tempat dengan tempat lain disebabkan oleh berbagai hal, diantaranya penggunaan jarak tanam dan varietas yang kurang sesuai dengan agroklimat setempat. Agar penggunaan jarak tanam dan varietas sesuai dengan agroklimat diperlukan sosialisasi teknologi budidaya untuk meningkatkan pengetahuan dan keterampilan petani agar dapat terjadi perubahan sikap dalam mengadopsi inovasi pertanian yang dapat diterapkan dalam mengelola usaha taninya menjadi lebih baik .

Jagung memiliki banyak macam dimana varietasvarietas jagung ini mulai diperkenalkan guna melihat kualitas jagung tersebut, dan dengan adanya upaya yang dilakukan pemerintah juga dalam menggenjot produksi pertanaman jagung(Puslitbangtan,2013). Produksi jagung sangat dipengaruhi lingkungan tumbuh yang sesuai. Setia jenis jagung memiliki perbedaan linkungan tumbuh yang berbeda. Menurut Amzeri (2015), bahwa produksi maksimal dari jagung dapat diperoleh jika lingkungan tumbuh sesuai dengan 
kebutuhan tanaman yaitu suhu, kelembaban, cahaya, dan air serta hormon pada tanaman.

\section{Metodologi}

Penelitian ini dilaksanakan di Desa Tumpiling, Kecamatan Wonomulyo Kabupaten Polewali Mandar. Titik ordinat $-3,399388$ (LAT), S3023'58,41114 dan Garis Bujur (Long) 119,195141, E 118 ${ }^{\circ} 11^{\prime} 42,50717^{\prime \prime}$ dengan ketinggian $43 \mathrm{~m}$ dpl. Berlangsung pada bulan Januari-April 2019. Lahan yang digunakan adalah lahan sawah beririgasi. Bahan yang digunakan dalam penelitian ini adalah, benih jagung BISI 18, Pertiwi, OPV Srikandi A. Depu, Anoman 1, Bima 12 Q, URI 3 dan Sukmaraga, air, pupuk kandang kambing, pupuk urea. Sedangkan alat yang digunakan ialah cangkul, parang, ember, meteran, tali rapia, tugal, gunting, timbangan, alat tulis menulis dan kamera.

Penelitian ini dilakukan dengan menggunakan Rancangan Acak Kelompok (Randomized Blok Design), terdiri atas 7 varietas, yakni :BISI 18 (V1), Pertiwi (V2), OPV Srikandi A. Depu (V3), Anoman 1(V4), Bima 12 Q (V5), URI 3 (V6) dan Sukmaraga (V7). Sehingga terdapat 7 unit perlakuan dan setiap unit perlakuan diulang sebanyak 3 kali, sehingga akan didapatkan 21 unit penelitian. Setiap unit penelitian berukuran $3 \times 3 \mathrm{~m}$ dengan jarak tanaman $70 \times 20$ $\mathrm{cm}$ dan terdiri dari 64 tanaman pada setiap unit, sehingga akan terdapat keseluruhan 1.344 tanaman.

\section{Hasil Dan Pembahasan}

\section{Tinggi Tanaman}

Data pengamatan tinggi tanaman disajikan pada Tabel 1. Sidik ragam menunjukkan rata-rata tinggi tanaman berpengaruh nyata pada umur 2 MST, dan berpengaruh sangat nyata pada umur 6, 8 dan 10 MST, Sedangkan pada umur 4 MST tidak memperlihatkan pengaruh nyata.

Tabel 1. Rata-rata Tinggi Tanaman (cm) Jagung Pada Berbagai Varietas Yang Sesuai Agroekosistem Kab. Polewali Mandar.

\begin{tabular}{lccccc}
\hline VARIETAS & 2 MST & 4 MST & 6 MST & 8 MST & 10 MST \\
\hline BISI 18 & $46,78^{\mathrm{a}}$ & $118,78^{\text {th }}$ & $224,22^{\mathrm{ab}}$ & $297,33^{\mathrm{bc}}$ & $300,78^{\mathrm{b}}$ \\
PERTIWI & $54,22^{\mathrm{b}}$ & $131,56^{\text {th }}$ & $235,89^{\mathrm{bc}}$ & $287,22^{\mathrm{bc}}$ & $286,78^{\mathrm{b}}$ \\
OPV SRIKANDI A. & $51,00^{\mathrm{b}}$ & $133,33^{\text {th }}$ & $235,67^{\mathrm{bc}}$ & $279,56^{\mathrm{b}}$ & $284,22^{\mathrm{b}}$ \\
DEPU & $54,33^{\mathrm{b}}$ & $136,00^{\text {th }}$ & $246,78^{\mathrm{c}}$ & $284,11^{\mathrm{bc}}$ & $287,33^{\mathrm{b}}$ \\
ANOMAN 1 & $46,33^{\mathrm{a}}$ & $116,55^{\text {th }}$ & $217,00^{\mathrm{a}}$ & $281,33^{\mathrm{b}}$ & $287,44^{\mathrm{b}}$ \\
BIMA 12 Q & $49,67^{\mathrm{ab}}$ & $127,56^{\text {th }}$ & $220,11^{\mathrm{ab}}$ & $226,33^{\mathrm{a}}$ & $227,11^{\mathrm{a}}$ \\
URI 3 & $51,67^{\mathrm{b}}$ & $127,89^{\text {th }}$ & $261,00^{\mathrm{d}}$ & $315,67^{\mathrm{c}}$ & $317,22^{\mathrm{b}}$ \\
SUKMARAGA & 4,71 & & & & \\
\hline NP BNT 0.05 & & & 15,89 & 34,25 & 35,25 \\
\hline NP BNT 0.01 & & & & \\
\hline
\end{tabular}

Keterangan: Angka yang diikuti oleh huruf yang berbeda pada uji BNT berarti berbeda nyata, sedangkan tn berarti berbeda tidak nyata

Hasil Uji BNT pada Tabel 1 memperlihatkan bahwa Varietas Anoman 1 memberikan rata-rata tinggi tanaman terbaik pada umur 2 MST, dan berbeda nyata dengan BISI 18, Bima 12 Q, tetapi tidak berbeda nyata dengan Pertiwi, Opv srikandi A.Depu, Uri 3 dan Sukmaraga. Sedangkan pada 6,8 dan 10 MST rata-rata hasil tertinggi pada varietas
Sukmaraga. Tinggi tanaman merupakan salah satu komponen pertumbuhan yang dapat dijadikan parameter adaptasi suatu varietas jagung terhadap lingkungan tumbuh. Sifat tinggi tanaman dapat dipengaruhi oleh faktor genetik dan lingkungan atau interaksi antar lingkungan dengan genetik. Hal ini disebabkan oleh sifat tanaman yang tinggi mampu menerima intensitas cahaya secara penuh, sehingga proses fotosintesa tanaman berlangsung optimal (Soehendi dan Syahri, 2013). Optimalisasi fotosintesis tanaman tersebut meningkatkan suplai bahan kering ke daun, batang dan biji sehingga memicu pertumbuhan dan biomas tanaman. Cahaya matahari dan curah hujan sangat mempengaruhi pertumbuhan dan produksi jagung. (Patta et.al., 2010), dan (Amir dan Basir, 2013).

\section{Jumlah Daun}

Data pengamatan jumlah daun disajikan pada Tabel 2. Sidik ragam menunjukkan bahwa uji berbagai varietas jagung memberikan pengaruh nyata terhadap parameter jumlah daun 8 MST, tetapi tidak berpengaruh nyata terhadap jumlah daun pada umur 2, 4, dan 6 MST.

Tabel 2. Rata-rata Jumlah Daun (helai) Jagung Pada Berbagai Varietas yang Sesuai Agroekosistem Kab. Polewali Mandar.

\begin{tabular}{lcccc}
\hline VARIETAS & 2 MST & $\mathbf{4}$ MST & 6 MST & $\mathbf{8}$ MST \\
\hline BISI 18 & $4,67^{\text {tn }}$ & $8,89^{\text {tn }}$ & $13,00^{\text {tn }}$ & $16,11^{\mathrm{b}}$ \\
PERTIWI & $5,11^{\text {tn }}$ & $9,22^{\text {tn }}$ & $13,11^{\text {tn }}$ & $16,11^{\mathrm{b}}$ \\
OPV SRIKANDI A. DEPU & $5,78^{\text {tn }}$ & $8,56^{\text {tn }}$ & $13,00^{\text {tn }}$ & $14,44^{\mathrm{ab}}$ \\
ANOMAN 1 & $4,89^{\text {tn }}$ & $9,00^{\text {tn }}$ & $13,56^{\text {tn }}$ & $14,44^{\mathrm{ab}}$ \\
BIMA 12 Q & $5,00^{\text {tn }}$ & $8,78^{\text {tn }}$ & $12,56^{\text {tn }}$ & $14,44^{\mathrm{ab}}$ \\
URI 3 & $5,44^{\text {tn }}$ & $9,22^{\text {tn }}$ & $12,11^{\text {tn }}$ & $12,33^{\mathrm{a}}$ \\
SUKMARAGA & $5,44^{\text {tn }}$ & $9,67^{\text {tn }}$ & $13,44^{\text {tn }}$ & $14,22^{\mathrm{a}}$ \\
\hline NP BNT 0.01 & & & & 2,38
\end{tabular}

Keterangan: angka yang diikuti oleh huruf yang berbeda pada uji BNT berarti berbeda nyata, sedangkan tn berarti berbeda tidak nyata

Hasil Uji BNT pada Tabel 2 memperlihatkan bahwa Varietas BISI 18 dan Pertiwi memberikan hasil terbaik dan berbeda nyata dengan varietas lainnya pada parameter jumlah daun hal ini diduga jumlah daun dipengaruhi oleh faktor genotype dan lingkungan, jumlah daun yang banyak akan dapat memberikan kontribusi besar terhadap aktivitas fotosintesis tanaman karena daun merupakan organ tanaman yang berfungsi sebagai termpat terjadinya fotosintesis (Kartahadimaja, 2009) dan (Yati H dan Anna S, 2016). Jumlah daun digunakan untuk mengetahui pertumbuhan dan hasil tanaman jagung, selain itu untuk mempengaruhi besaran atau banyak cahaya matahari pada masing-masing tanaman melalui klorofil daun dalam pembentukan makanan, serta tanaman yang kekurangan unsur hara akan mengakibatkan terhambatnya pembentukan atau pertumbuhan bagian vegetative tanaman. (Eko C.J, dan Herlina N, 2018). Menurut Taufik etal., (2010),bahwa unsur hara yang diserap akan diakumulasi di daun menjadi protein yang dapat membentuk biji, dengan terpenuhinya kebutuhan hara tanaman menyebabkan metabolisme berjalan secara optimal sehingga pembentukan protein, karbohidrat dan pati tidak terhambat, akibatnya akumulasi bahan hasil metabolisme pada pembentukan bijiakan meningkat menyebabkan biji yang terbentuk memiliki ukuran dan berat yang maksimal. 


\section{Umur BerbungaJantan}

Data pengamatan Umur berbunga jantan disajikan pada Tabel 3. Sidik ragam menunjukkan uji berbagai varietas jagung yang sesuai agroekosistem polewali mandar berpengaruh sangat nyata pada pengamatan umur berbungaj antan.

Tabel 3. Rata-rata Umur berbunga (Hari) Jagung Pada Berbagai Varietas Yang Sesuai Agroekosistem Kab. Polewali Mandar.

\begin{tabular}{lcc}
\hline VARIETAS & RATA-RATA & NP BNT 0.01 \\
\hline BISI 18 & $50,67^{\mathrm{e}}$ & 1.43 \\
PERTIWI & $47,67^{\mathrm{d}}$ & \\
OPV SRIKANDI A. DEPU & $46,33^{\mathrm{cd}}$ \\
ANOMAN 1 & $45,33^{\mathrm{bc}}$ \\
BIMA 12 Q & $46,33^{\mathrm{cd}}$ \\
URI 3 & $38,33^{\mathrm{a}}$ \\
SUKMARAGA & $44,67^{\mathrm{b}}$ \\
\hline Keterangan: Angka yang diikuti oleh huruf yang bebrbeda pada uji BNT \\
\multicolumn{2}{l}{ berarti berbeda nyata }
\end{tabular}

Hasil Uji BNT pada Tabel 3 memperlihatkan bahwa Varietas URI 3 memberikan hasil rata-rata terbaik dan berbeda nyata dengan 6 varietas lainnya, yaitu 38,33 hari. Hal ini diduga dipengaruhi oleh faktor lingkungan dan genetik. Umur keluar malai dan rambut tongkol yang lebih cepat dapat meningkatkan hasil biji jagung, hal ini diduga berkaitan dengan lamanya periode pengisian biji karena tanaman yang berbunga lebih awal menyebabkan masa pengisian biji juga lebih lama (Wangiyana, et. al., 2013. Percepatan umur keluar malai dan rambut tongkol dapat meningkatkan hasil biji jagung, hal ini diduga berkaitan dengan lamanya periode pengisian biji karena tanaman yang berbunga lebih awal menyebabkan masa pengisian biji lebih lama dan optimal.

\section{Panjang Tongkol}

Data pengamatan panjang tongkol disajikan pada Tabel 4. Sidik ragam menunjukkan bahwa uji berbagai varietas jagung berpengaruh sangat nyata pada pengamatan panjang tongkol.

Tabel 4. Rata-rata panjang tongkol $(\mathrm{cm})$ Jagung Pada Berbagai Varietas Yang Sesuai Agroekosistem Kab. Polewali Mandar.

\begin{tabular}{lcc}
\hline VARIETAS & RATA-RATA & NP BNT 0.01 \\
\hline BISI 18 & $19,94^{\mathrm{c}}$ & 2,26 \\
PERTIWI & $18,61^{\mathrm{bc}}$ & \\
OPV SRIKANDI A. DEPU & $19,72^{\mathrm{c}}$ & \\
ANOMAN 1 & $18,72^{\mathrm{bc}}$ \\
BIMA 12 Q & $16,67^{\mathrm{ab}}$ & \\
URI 3 & $15,83^{\mathrm{a}}$ & \\
SUKMARAGA & $20,50^{\mathrm{c}}$ & \\
\hline
\end{tabular}

Keterangan: Angka yang diikuti oleh huruf yang bebrbeda pada uji BNT berarti berbeda nyata

Hasil Uji BNT pada Tabel 4 memperlihatkan bahwa Varietas Sukmaraga memberikan hasil tertinggi dan berbeda nyata dengan URI 3, BIMA 12 Q tetapi tidak berbeda dengan varietas lainnya untuk panjang tongkol tanaman jagung dengan nilai rata-rata $20,50 \mathrm{~cm}$. Hal ini disebabkan varietas tanaman mampu memanfaatkan faktor lingkungan secara optimal sehingga tanaman dapat memperoleh unsur hara, air, sinar matahari yang cukup dan mempunyai ruang gerak yang lebih luas untuk pertumbuhan dan perkembangan akarnya. Penampilan suatu karakter akan optimal dalam hal ini panjang tongkol pada tanaman jagung jika tanaman tersebut berada pada lingkungan yang sesuai, sebaliknya penampilan tidak akan optimal jika berada pada lingkungan yang tidak sesuai. Penampilan suatu karakter yang heritabilitasnya tinggi memiliki pengaruh lingkungan sedikit sehingga penampilannya akan relatif tetap, tetapi karakter yang heritabilitasnya rendah memiliki pengaruh lingkungan yang besar sehingga penampilannya mudah berubah (Soehendi dan Syahri, 2013).

\section{Berat Tongkol dengan Kelobot}

Data pengamatan berat tongkol dengan kelobot disajikan pada tabel Gambar 1. Sidik ragam menunjukkan bahwa uji berbagai varietas jagung tidak berpengaruh nyata pada pengamatan berat tongkol dengan kelobot.

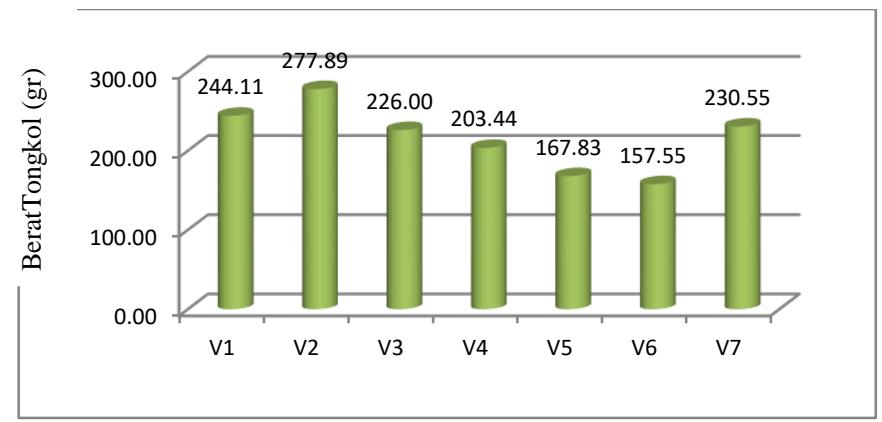

Gambar 1. Rata-rata berat tongkol dengan kelobot (gr) Jagung pada Berbagai Varietas yang Sesuai Agroekosistem Kab. Polewali Mandar.

Gambar 1 menunjukkan bahwa varietas Pertiwi (V2) memberikan hasil berat tongkol dan kelobot tertinggi dibandingkan varietas lain dengan berat 277,89 gram, hal ini diduga karena dipengaruhi oleh faktor genetik, sedangkan kemampuan tanaman untuk memunculkan karakter genetiknya dipengaruhi oleh faktor lingkungan. Berat Tongkol dengan kelobot hal ini sangat dipengaruhi oleh ketersediaan nitrogen, dimana nitrogen merupakan komponen utama dalam proses sintesa protein. Apabila sintesa protein berlangsung baik maka akan berkorelasi positif terhadap peningkatan ukuran dan massa tanaman dalam hal ini berat tongkol dengan kelobot (Tarigan, 2007)

\section{Jumlah Biji Dalam Baris}

Data pengamatan jumlah biji dalam baris disajikan pada tabel lampiran 5. Sidik ragam menunjukkan bahwa uji berbagai varietas jagung memberikan pengaruh nyata pada pengamatan jumlah biji dalam baris. 
Tabel 5. Rata-rata Jumlah Biji Dalam Baris (biji) Jagung Pada Berbagai Varietas Yang Sesuai Agroekosistem Kab. Polewali Mandar.

\begin{tabular}{lcc}
\hline VARIETAS & RATA-RATA & NP BNT 0.01 \\
\hline BISI 18 & $39,89^{\mathrm{c}}$ & 3,63 \\
PERTIWI & $40,00^{\mathrm{c}}$ & \\
OPV SRIKANDI A. DEPU & $38,33^{\mathrm{bc}}$ & \\
ANOMAN 1 & $37,33^{\mathrm{bc}}$ & \\
BIMA 12 Q & $34,89^{\mathrm{ab}}$ & \\
URI 3 & $32,34^{\mathrm{a}}$ \\
SUKMARAGA & $39,22^{\mathrm{c}}$ \\
\hline
\end{tabular}

Keterangan: Angka yang diikuti oleh huruf yang bebrbeda pada uji BNT berarti berbeda nyata

Hasil Uji BNT pada Tabel 5 menunjukkan bahwa Varietas Pertiwi memiliki jumlah biji dalam baris terbaik namun tidak berbeda nyata dengan BISI 18 dan Sukmaraga tetapi berbeda nyata dengan varietas lainnya. Hal ini disebabkan oleh varietas tanaman dan faktor lingkungan. Menurut Hakim (2008) bahwa setiap varietas mempunyai susunan genetik yang tidak sama dan kemampuan varietas itu sendiri dalam beradaptasi dengan lingkungan tumbuhnya, sehingga tetap menghasilkan pertumbuhan yang baik dan hasil maksimal. Susilowati (2001) mengatakan bahwa jumlah biji dalam baris mempengaruhi produksi tanaman jagung, selanjutnya Nurhayati (2002) menyatakan bahwa peningkatan jumlah biji dalam baris juga berhubungan erat dengan besaran fotosintat yang dialirkan ke bagian tonkol untuk pembentukan jumlah biji.

\section{Berat Biji Kering}

Data pengamatan berat biji kering dan sidik ragam disajikan pada tabel lampiran 14a dan 14b. Sidik ragam menunjukkan

bahwaujiberbagaivarietasjagungmemberikanpengaruhsangatn yataterhadap pengamatan berat biji kering.

Tabel 6. Rata-rata Berat Biji Kering (kg) Jagung Pada Berbagai Varietas Yang Sesuai Agroekosistem Kab. Polewali Mandar.

\begin{tabular}{lcc}
\hline VARIETAS & RATA-RATA & NP BNT 0.01 \\
\hline BISI 18 & $7,17^{\mathrm{c}}$ & 2,04 \\
PERTIWI & $7,67^{\mathrm{c}}$ & \\
OPV SRIKANDI A. DEPU & $5,33^{\mathrm{ab}}$ & \\
ANOMAN 1 & $5,00^{\mathrm{ab}}$ & \\
BIMA 12 Q & $4,30^{\mathrm{ab}}$ & \\
URI 3 & $3,87^{\mathrm{a}}$ & \\
SUKMARAGA & $5,97^{\mathrm{bc}}$ & \\
\hline
\end{tabular}

Keterangan: Angka yang diikuti oleh huruf yang bebrbeda pada uji BNT berarti berbeda nyata

Hasil Uji BNT pada Tabel 6 memperlihatkan bahwa Varietas Pertiwi memiliki berat biji terbaik namun tidak berbeda nyata dengan varietas BISI 18 tetapi berbeda sangat nyata dibanding varietas lainnya hal ini diduga ketersediaan hara pada tanaman selama proses pembentukan biji tersedia dan tercukupi. Menurut Novizan (2002) bahwa hara mempengaruhi bobot tongkol terutama biji, karena hara yang diserap oleh tanaman akan digunakan untuk pembentukan protein, karbohidrat, dan lemak nantinya akan disimpan dalam biji sehingga akan meningkatkan bobot biji pada tanaman.

\section{Produktivitas}

Data pengamatan produktivitas pada tabel 7. Sidik ragam menunjukkan bahwa uji baerbagai varietas jagung berpengaruh sangat nyata pada parameter pengamatan produktifitas tanamanjagung.

Tabel 7. Produktivitas (ton/ha) Jagung Pada Berbagai Varietas Yang Sesuai Agroekosistem Kab. Polewali Mandar.

\begin{tabular}{lcc}
\hline VARIETAS & RATA-RATA & NP BNT 0.01 \\
\hline BISI 18 & $7,96^{\mathrm{c}}$ & 2,29 \\
PERTIWI & $8,52^{\mathrm{c}}$ & \\
OPV SRIKANDI A. DEPU & $5,93^{\mathrm{ab}}$ & \\
ANOMAN 1 & $5,55^{\mathrm{ab}}$ & \\
BIMA 12 Q & $4,77^{\mathrm{ab}}$ & \\
URI 3 & $4,30^{\mathrm{a}}$ & \\
SUKMARAGA & $6,63^{\mathrm{bc}}$ &
\end{tabular}

Keterangan: Angka yang diikuti oleh huruf yang bebrbeda pada uji BNT berarti berbeda nyata

Hasil Uji BNT pada Tabel 7 memperlihatkan bahwa Varietas Pertiwi memiliki produktivitas terbaik namun tidak berbeda nyata dengan BISI 18 dan Sukmaraga tetapi berbeda nyata dengan varietas lainnya dengan nilai rata-rata 8,52 ton/ha hal ini disebabkan oleh adanya pengaruh genotype pada tanaman jagung. Upaya peningkatan produksi jagung pada lahan akan lebih berhasil bila menggunakan varietas unggul jagung yang adaptif (Amir dan Basir, 2013). Genotipe yang berbeda akan memberikan tanggapan yang berbeda meskipun di lingkungan yang sama. Penggunaan varietas unggul baru yang dikombinasikan dengan penggunaan pupuk yang tepat memberikan kontribusi dalam peningkatan produksi jagung (Sirrapa dan Nurdin, 2010). Pengisian tongkol jagung dipengaruhi oleh suplai hara untuk membentuk asimilat selama periode pertumbuhan dan pengisian tongkol. Dengan persediaan asimilat cukup, pertumbuhan tongkol dan pengisian biji optimal sehingga dapat meningkatkan produktivitas jagung

\section{Kesimpulan}

Dari hasil penelitian yang dilakukan maka dapat ditarik kesimpulan sebagai berikut : Benih jagung Varietas Pertiwi, Varietas Anoman 1, Varietas BISI 18, Varietas URI 3, Varietas Sukmaraga yang merupakan benih unggul dan cocok ditanam pada Agroekosistem Kabupaten Polewali Mandar dengan menunjukan pertumbuhan vegetative yang lebih baik. Varietas Hibrida Pertiwi memberikan pengaruh yang baik dan menghasilkan produktivitas tertinggi tetapi tidak berbeda dengan Hibrida BISI 18 dan Non Hibrida Sukmaraga 


\section{Daftar Pustaka}

Amir dan Basir Nappu M, 2013. Uji Adaptasi Beberapa Varietas Jagung Hibrida pada Lahan Sawah Tadah Hujan di Kabupaten Takalar. Seminar Nasional Inovasi Teknologi Pertanian. Balai Pengkajian Teknologi Pertanian Sulawesi Selatan. Sulawesi Selatan.

Departemen Pertanian, 2016. Pertumbuan Jagung Indonesia. Suara Pustaka Pertanian. Jakarta.Deptan. Tanggal akses 21 desember 2018 pukul 21.25 wita.

Eko Cahya Jamil dan Herlina Ninuk. 2018. Uji Potensi Enam Varietas Jagung Manis (Zea mays saccharate Sturt) di Dataran Rendah Kabupaten Pamekasan. Jurnal Produksi Tanaman. Universitas Brawijaya. Malang

Fredi Kurniawan. 2016 " Syarat Tumbuh Tanaman Jagung “ http://fredikurniawan.com/syarat-tumbuh-tanamanjagung/Diakses pada 19 Oktober 2018.

Gamaliel 2017, “ Klasifikasi Tanaman Jagung “, sumber : http://www-agroindustri-id./klasifikasi-dan-morfologijagung/amp

Handoko Sigit dan Takdir Mulyadi Muhammad. 2017. Uji Adaptasi Varietas Unggul Baru (VUB) Jagung Hibrida sebagai Upaya Pemanfaatan Lahan Sub Optimal di Kabupaten Tanjung Jabung Timur Provisi Jambi. Balai Pengkajian Teknologi Pertanian Jambi. Jambi.

Hakim, L.N. 2008. Pengaruh waktu tanam jagung dan varietas kacang tanah pada sistemTumpang sari Terhadap pertumbuhan dan Hasil kedua Tanaman. Skripsi. FakultasPertanianSyiah Kuala. Banda Aceh.

Haris Kuruseng dan Askari Kuruseng, M.2009. Pertumbuhan Dan Produksi Berbagai Varietas Tanaman Jagung Pada Dua Dosis PupukUrea. JurnalAgrisistem,4 (1): 26-36

Ichsan, 2014. "Syarat tumbuh tanaman jagung" sumber :https://www.petanihebat.com/syarat-tumbuhtanaman-jagung/. Diakses pada 30 Oktober 2018.

Kartahadimaja, J. 2009. Potensi Hasil Tiga Belas Galur Jagung Hibrida Silang Tunggal Rakitan Politeknik Negeri Lampung. Jurnal Penelitian PertanianTerapan, 10 (1): $17-22$

Murni dkk., 2008. Teknologi Budidaya Jagung. Bogor: Balitbang Pertanian,

Novizan, 2002. Petunjuk Pemupukan yang Efektif pada Tanaman. Agromedia Pustaka. Jakarta

Nurhayati, 2002. Pengaruh Takaran Pupuk Kandang dan Umur Panen Terhadap Hasil dan Kandungan Gula Jagung Manis Skripsi. Fakultas Pertanian Universitas Terbuka. 42 hal

Paeru, R. H. dan T. Q. Dewi. 2017. Panduan Praktis Budidaya Jagung. Penebar Swadaya, Jakarta.

Patta, S. dan Syafruddin, 2010. Uji Adaptasi Varietas Bima di Lahan Kering. Prosiding Pekan Serealia Nasional. ISBN : 978-979-8940-23-3. Balai Penelitian Serealia.Pusat Penelitian dan Pengembangan Tanaman Pangan, KementerianPertanian.

Riwandi. 2014. Teknik Budidaya Jagung dengan Sistem Organik di Lahan Marjinal. UNIB Press. Bengkulu.

Roney, John (Winter 2009). "The Beginning sofMaize Agriculture". Archaeology South west. 23 (1): 4
Sirrapa, M., P., dan Nurdin, M. 2010.Tanggapan Varietas Jagung Hibrida Dan Komposit Pada Pemberian Pupuk Tunggal N, P, K Dan Pupuk Kandang Di Lahan Kering. Jurnal Agrotropika,15(2): 49-55

Soehendi, R. danSyahri. 2013. Potensi Pengembangan Jagung di Sumatera Selatan. Jurnal Lahan Suboptimal,2 (1): 81-92

State University, Department of Agronomy , 2014. Origin, History and Usesof Corn". Iowa.

Subekti dkk,. 2008. Morfologi Tanaman dan Fase Pertumbuhan Jagung. Balai Penelitian Serealia Maros. Tersedia dalam http://balitsereal.litbang.deptan.go.id/ind/bjagung/emp at.pdf.

Susilowati, 2001. Pengaruh Pupuk Kalium Terhadap Pertumbuhan dan Hasil Jagung Manis (Zea mays saccharate Sturt). Jurnal Budidaya Pertanian.Vol 7(1) : 36-45.

Syariefa, 2012. Budidaya dan Produksi Jagung. Benta Jaya, Bandung.

Taufik, M., Suprapto dan Widiyono, H. 2010. Uji Daya Hasil Pendahuluan Jagung Hibrida di Lahan Ultisol dengan Input Rendah. Akta Agrosia,13(1): 70-76.

Tarigan, Ferry H. 2007. Pengaruh Pemberian Pupuk Organik Green Giant dan Pupuk Daun Super Bionik terhadap Pertumbuhan dan Produksi Tanaman Jagung (Zea mays L). Jurnal Agrivigor 23 (7): 10-18

Widowati,S.2012 Sehat Dengan Pangan Indeks Glikemik Rendah. Warta penelitian Vol.29.No. 3

Wangiyana, W.,Ngawit, I.K., Hanan, M.2013.Peningkatan Hasil Jagung Hibrida Var. BISI-2 Dengan Aplikasi Pupuk Kandang Sapi Dan peningkatan Frekuensi Pemberian Urea Dan Campuran SP-36 Dan KCl. Jurnal Agroteknologi, 1(2):56-75.

Yati Haryati dan Anna Sinaga, 2016. Pengujian Adaptasi Beberapa Varietas Jagung Hibrida Spesifik Lokasi di Kabupaten Majalengka. Badan Pengakajian Tanaman Pangan Jawa Barat. Majalengka.

Puslitbangtan, 2013. Deskripsivarietastanamanjagungedisi 2013. Puslitbangtan;151 hlm 